\title{
The Economic Impact Of The Film And Video Production And Distribution Industry On The Charlotte Regional Economy
}

John E. Connaughton, University of North Carolina at Charlotte, USA Ronald A. Madsen, University of North Carolina at Charlotte, USA

\begin{abstract}
This report provides measurement of the 2008 economic impacts of the film and video production and distribution industry on the Charlotte regional economy. Officially known as the Charlotte USA Region, this 16 county area is one of America's fastest-growing metropolitan regions and supports a well established and expanding film and video production and distribution industry. Four different types of economic impacts generated by the film and video production and distribution industry were estimated based on the 2008 information. These impacts include: (1) output impacts; (2) employment impacts; (3) employee and freelancers compensation impacts; and (4) value added impacts. The results are disaggregated to identify the direct economic impact of the film and video production and distribution industry, the indirect (supply chain) impact of the industry, and the induced (re-spending) impact of the industry. The total impact of the industry is then the sum of direct, indirect, and induced impacts.
\end{abstract}

Keywords: economic impact studies; film and video industry; local economy

INTRODUCTION

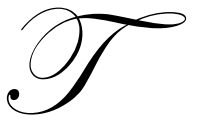

his report provides measurement of the 2008 economic impacts of the film and video production and distribution industry on the Charlotte regional economy. This regional economy is centered by Charlotte and composed of twelve North Carolina counties and four South Carolina counties. Officially known as the Charlotte USA Region, this 16 county area is one of America's fastest-growing metropolitan regions and supports a well established and expanding film and video production and distribution industry. Four different types of economic impacts generated by the film and video production and distribution industry were estimated based on the 2008 information. These impacts include: (1) output impacts; (2) employment impacts; (3) employee and freelancers compensation impacts; and (4) value added impacts. The report was sponsored by the Charlotte Regional Partnership and conducted by the Belk College of Business, University of North Carolina Charlotte.

\section{Background}

The Area: Figure 1 identifies the sixteen counties in the Charlotte Regional Partnership Economic Area. This area is anchored by the city of Charlotte, and Mecklenburg County, and has over 2.5 million people with a land area of just over 8,000 square miles. In this study, these sixteen counties are referred to as the Charlotte Region. The Appendix provides economic and demographic details on each of the sixteen counties.

This region provides a combination of urban and rural, foothills and flatlands, small towns and large city locations. Additionally, the Charlotte Region contains numerous rivers and lakes, including Lake Norman and Lake Wylie. All told there are 1,770 miles of shoreline in the region. 
The Charlotte USA Region has a strong and established film and video production industry. Charlotte is home to four major equipment companies, numerous sound stages, strong independent producers and crew base, several large television production organizations, and an array of marketing firms producing commercials for local and national distribution. The combined economic impacts of these organizations and individuals are the focus of this study.

Figure 1

Charlotte Regional Partnership Economic Area

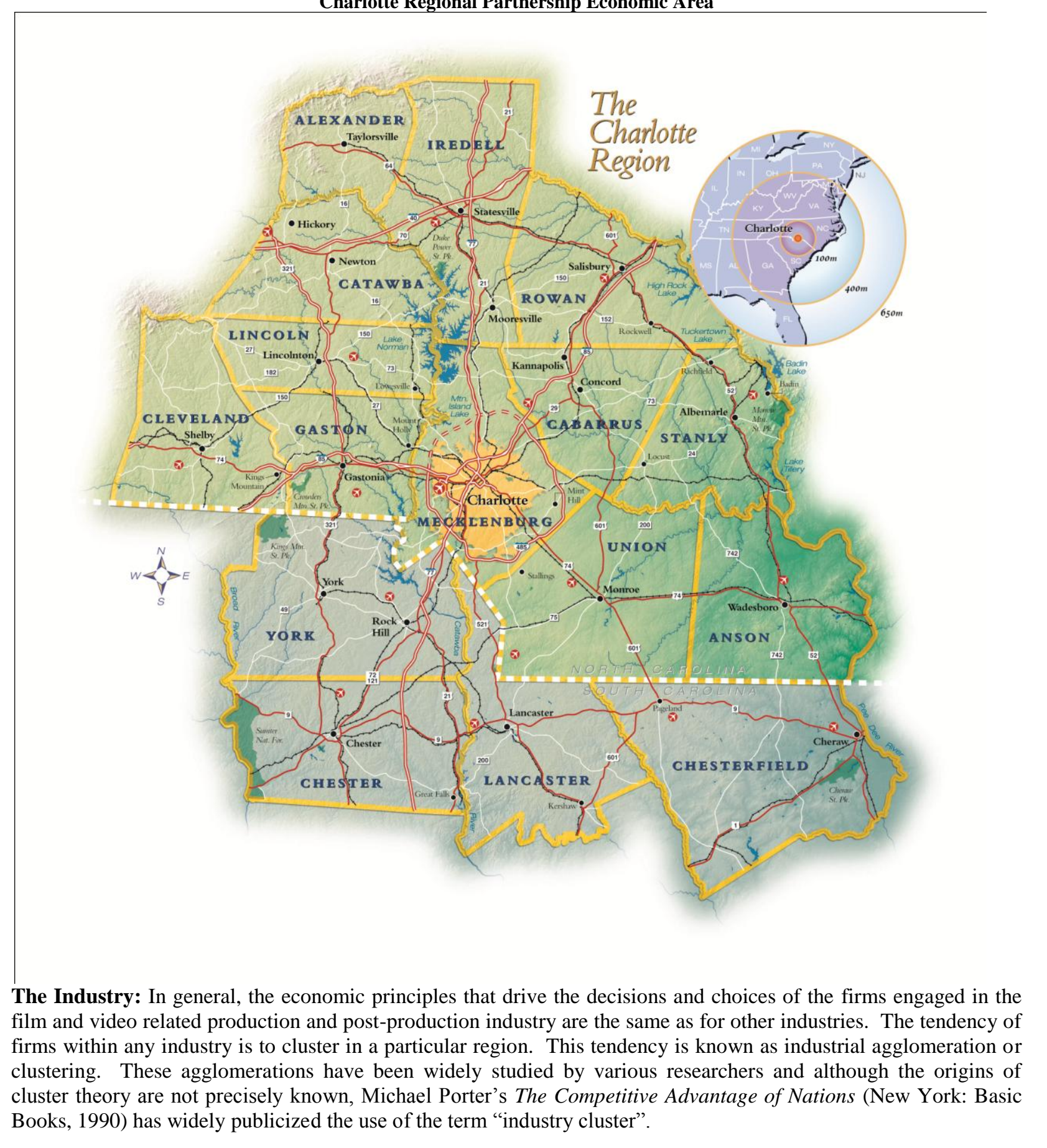


Based on Porter's analysis, an industry cluster is a group of companies that are related through at least one of the following types of relationships:

1. Buyer-Supplier Relationships

2. Competitor and Collaborator Relationships

3. Shared Resources Relationships

In this study, the cluster is made up of all of the firms, freelance individuals, and suppliers actively engaged in the production and distribution of feature films, short films, documentaries, television movies, television content (excluding news and sporting events), videos, and commercials. Table 1.1 contains average compensation levels for many of the job categories included in the film and video production and distribution industry. This table presents 2008 compensation levels reported for the Charlotte-Gastonia-Concord NC-SC Region by the U.S. Bureau of Labor Statistics.

Table 1.1

Charlotte Region

2008 Average Compensation Levels for Film and Video Industry

\begin{tabular}{|c|c|c|c|c|}
\hline $\begin{array}{c}\text { Occupation } \\
\text { Code }\end{array}$ & Occupation Title & $\begin{array}{l}\text { Median } \\
\text { Hourly }\end{array}$ & $\begin{array}{c}\text { Mean } \\
\text { Hourly }\end{array}$ & Mean Annual \\
\hline $27-2011$ & Actors & & & N/A \\
\hline $27-1011$ & Art Directors & $\$ 31.79$ & $\$ 38.64$ & $\$ 80,360$ \\
\hline $27-4011$ & Audio and Video Equipment Technicians & $\$ 18.34$ & $\$ 18.54$ & $\$ 38,560$ \\
\hline $27-4031$ & Camera Operators, Television, Video, and Motion Picture & $\$ 15.09$ & $\$ 16.62$ & $\$ 34,570$ \\
\hline $27-4032$ & Film and Video Editors & $\$ 16.91$ & $\$ 18.80$ & $\$ 39,100$ \\
\hline $27-4099$ & Media and Communication Equipment Workers, All Other & $\$ 18.84$ & $\$ 22.97$ & $\$ 47,780$ \\
\hline $27-1014$ & Multi-Media Artists and Animators & $\$ 23.55$ & $\$ 24.36$ & $\$ 50,660$ \\
\hline $27-4021$ & Photographers & $\$ 14.46$ & $\$ 15.85$ & $\$ 32,970$ \\
\hline $27-2012$ & Producers and Directors & $\$ 28.32$ & $\$ 30.27$ & $\$ 62,950$ \\
\hline $27-4014$ & Sound Engineering Technicians & $\$ 19.37$ & $\$ 21.23$ & $\$ 44,150$ \\
\hline $27-3043$ & Writers and Authors & $\$ 18.45$ & $\$ 21.91$ & $\$ 45,570$ \\
\hline $00-0000$ & All Occupation in North Carolina - 2008 & $\$ 13.92$ & $\$ 17.74$ & $\$ 36,900$ \\
\hline 00-0000 & All Occupation in South Carolina - 2008 & $\$ 13.16$ & $\$ 16.21$ & $\$ 33,720$ \\
\hline
\end{tabular}

Source: BLS 2008 Occupational Employment Statistics, http://www.bls.gov/oes/2008/may/oes_16740.htm

Table 1.1 shows that in general the employees and freelancers (individuals) that work in the Charlotte USA Region film and video industry are well paid. The table also provides the 2008 average compensation levels for all occupations in North Carolina and South Carolina. Average compensation levels in the Charlotte USA Region for most of the film and video occupations listed are well above both the North Carolina and South Carolina All Occupation compensation levels in 2008. These higher levels of compensation reflect the high levels of technical, creative, and managerial skills of the people who work in the film and video production and distribution industry.

\section{Literature: Previous Studies}

There have been a number of studies dealing with the economic impact of the film industry, or the film and video industry, on state economies. Many of these studies were motivated by a desire to justify tax credits aimed at attracting movie and video productions to the state. These studies include:

An Economic Analysis of Virginia's Film and Video Production-Distribution Industry, by Mary Nelson of Virginia Commonwealth University published in 2006. This study used an IMPLAN input-output model for the state to estimate the 2004 economic impacts of the film and video industry on the state economy and on three substate regional economies. The study showed a total state level impact on output of $\$ 510$ million, supporting 5,969 jobs in the industry and an additional 2,553 induced jobs from re-spending. The study also provides estimates of the hypothetical impact of each $\$ 10$ million of film production spending in the state. 
In a 2004 study, ESI Corporation authored Analysis of the Film and Video Industry in Arizona for the Arizona Department of Commerce. Based on 2003 data and using the IMPLAN input-output methodology, the study concluded that the film industry in Arizona increased output by $\$ 201$ million, and supported 1,277 direct and indirect jobs and an additional 427 induced jobs for a total state impact of 1,704 jobs with total wages of $\$ 56.6$ million.

ECONorthwest produced An Economic Impact Analysis for the Oregon Film \& Video Office published in 2006 estimating film and video industry impacts in Oregon in 2005. This study used a computer model (not identified) of Oregon that identified direct, indirect (supplier chain), and induced impacts for three separate segments of the film and video industry. These segments were "Indigenous Film and Video", "Out-of-State Film and Video", and "Television Broadcasting". This study estimates the direct impacts of the film and video industry on the 2005 Oregon economy to be $\$ 494.1$ million in output, \$200.5 million in wages and income, and 5,521 jobs. This study differs from others in that it includes the entire television and broadcasting segment, not just the content producing impact (excluding sporting events and news).

In 2003, ECONorthwest published a report, The Economic Impact of Film and Video Productions on Seattle, for the Seattle Mayor's Office of Film and Video. This study, based on 2001 data, used the input-output modeling approach and the IMPLAN model for the state of Washington. It concluded the film and video industry supported 2,266 direct jobs 1,511 indirect (supplier chain) jobs, and another 1,215 induced jobs for a total impact of 4,991 jobs. This impact was accompanied by a total output impact of $\$ 471.7$ million and total labor income of $\$ 186.4$ million. The decision to use a statewide model to estimate the impacts on the Seattle economy likely means the impacts for Seattle are somewhat overstated since leakages of some film and video activity, both indirect and induced, to the rest of the state were not modeled.

Other studies reviewed in the preparation of this report but not summarized, may be of interest and they include: Analysis of the Florida Film an Entertainment Industry (2009), The Economic Impact of Michigan's Motion Picture Industry (2007), The Big Sky on the Big Picture (2005), Economic and Fiscal Impacts of the New Mexico Film Production Tax Credit (2009), Evaluating the Economic Impacts of Film Production Incentives in South Carolina (2008), and Estimating the Impact of the Massachusetts Film Production Tax Incentives -A Preliminary Analysis (2008).

\section{STUDY METHODOLOGY}

Data Collection: Most industries in the U.S. economy have their own unique industry classification. U.S. industries are currently classified using the North American Industrial Classification System (NAICS). This system replaced the Standard Industrial Classification (SIC) system. These industrial classification systems assign firms a code based on the product or service the firm produces. This allows both the U.S. Bureau of Economic Analysis (BEA), which collects and publishes output and income data, and the U.S. Bureau of Labor Statistics (BLS), which collects and publishes employment and wage data, to compute total output, income, employment, and wages by a common industry code. The objective is for NAICS to provide aggregate industry specific data for homogeneous firm groupings.

However, some industry concepts, such as the film and video production and distribution industry, are not comprised of homogeneous firms within a unique NAICS code. The film and video production and distribution industry is comprised of firms and individuals (freelancers), that are classified in several different NAICS codes, based on the product or service they provide. An additional complication is that not all of the firms within each of these industry codes produce goods or services specifically related to film and video production and distribution industry. As a result, there is no comprehensive secondary film and video production and distribution data source for output, income, employment, or wages. This requires collection of primary data when no secondary data is available for a firm or individual in order to estimate the overall size and impact of the film and video production and distribution industry.

In this study data collection consisted of several different techniques. First, firms located in the Charlotte Region that were known to produce film and video production and distribution goods and services were identified 
using information provided by The Charlotte Regional Partnership, The Charlotte Regional Film Commission, interviews, and referrals provided by representative industry participants. This list of firms and individuals in the film and video production and distribution industry consists primarily of firms and individuals producing in the following NACIS's classifications:

51211 Motion Picture and Video Production: This industry is comprised of establishments primarily engaged in producing, or producing and distributing motion pictures, videos, television programs, or television commercials.

51219 Postproduction Services and Other Motion Picture and Video Industries: This industry is comprised of establishments primarily engaged in providing postproduction services and other services to the motion picture industry, including specialized motion picture or video postproduction services, such as editing, film/tape transfers, titling, subtitling, credits, closed captioning, and computer-produced graphics, animation and special effects, as well as developing and processing motion picture film.

541922 Commercial Photography: This U.S. industry is comprised of establishments primarily engaged in providing commercial photography services, generally for advertising agencies, publishers, and other business and industrial users. (For this study we exclude such activities as news, portrait, and event photography.)

Using the list of 514 firms and freelance individuals identified as operating in the Charlotte Region in the film and video production and distribution industry, information on 2008 operations was sought for each firm and freelancer. The initial technique of data collection involved the use of proprietary databases for firms. Firm and industry databases such as Reference USA and Dunn \& Bradstreet were utilized to collect the output and employment information for the firm's 2008 operations.

A telephone survey was conducted to collect information for freelancers on the list and for firms on which the proprietary databases failed to provide 2008 information. Callback procedures required repeated attempts to collect the desired information on 2008 operations.

Finally, despite all the different techniques of collecting primary data, output and employment data for a number of firms and individuals was incomplete. In order to estimate the missing data for these firms and freelancers, averages based on responding firms and individuals were used. Firm estimates were based on firm size classifications of small, medium, and large. For each firm class size and each freelancer, employment and output averages were calculated based on direct survey data, proprietary data, or a combination of both. The averaging technique that produced the most conservative estimate of employment and output was used to estimate the missing data.

Additionally, information on movie production expenditures in the Charlotte Region by movie companies located outside the Charlotte Region was provided by The Charlotte Regional Film Commission. Because of the "lumpy" nature of these expenditures (from year to year there can be large variation in the activities of outside movie companies in the Charlotte Region) the average annual level of this type of expenditure from the past several years was used for the study. This was done to give the feature film component its most representative level of impact on the overall economic impact of the film and video production and distribution industry on the Charlotte Region.

Impact Methodology: The economic impact of an industry or event is typically measured in terms of total output and/or jobs. To accurately assess the total economic impact, the most important piece of information is direct output or direct employment. The term direct refers to the dollar output or employment level associated with the firm or industry being evaluated. For this film and video production and distribution industry impact study, the term direct is most closely associated with the total annual sales/revenue generated by the different organizations that comprise the film and video production and distribution industry in the Charlotte Region.

Once the estimates of direct output and employment are established, the multiplier concept can then capture the total effect of the economic activity on output, employment, value added, and employee and freelancers' compensation. For instance, a job multiplier of 1.86 would mean that for each direct job in an industry, 0.86 
additional jobs are generated in other parts of the economy (the total benefit to the economy being 1.86 jobs). Thus, an event or firm that creates 100 new jobs in a particular industry would, through the multiplier effect, translate into a subsequent employment gain of 86 jobs in other sectors, for a total employment gain of 186 jobs (100 x 1.86$)$.

The basic multiplier methodology used in the film and video production and distribution industry study is provided by the Minnesota IMPLAN Group. IMPLAN is a multiplier methodology originally developed by the United States Forest Service to assist federal agencies in their land and resource management planning. This methodology is now widely used for economic impact studies and is maintained by the Minnesota IMPLAN Group.

For the Charlotte Region economy an IMPLAN multiplier model was constructed for the sixteen North and South Carolina counties identified earlier. The Input/Output (I/O) matrix for the region provides multipliers based on the new North American Industrial Classification System (NAICS) definitions of industries. The IMPLAN data used to estimate the region specific industry multipliers were based on 2004 data and adjusted for inflation to reflect the estimated effects in 2008. Table 2.1 presents the IMPLAN multipliers used in this study.

Table 2.1

IMPLAN Multipliers for the Charlotte Region Economy Multipliers

\begin{tabular}{|l|c|c|c|c|c|c|}
\hline \multicolumn{1}{|c|}{ Item } & IMPLAN Code & Industry & Direct & Indirect & Induced & Total \\
\hline Output & 418 & $\begin{array}{c}\text { Motion picture } \\
\text { and video industries }\end{array}$ & 1 & 0.529141 & 0.197113 & 1.726254 \\
\hline Employment & 418 & $\begin{array}{c}\text { Motion picture } \\
\text { and video industries }\end{array}$ & 1 & 0.519137 & 0.235382 & 1.754519 \\
\hline Employment/Million \$ & 418 & $\begin{array}{c}\text { Motion picture } \\
\text { and video industries }\end{array}$ & 5.150954 & 2.674010 & 1.212437 & 9.037401 \\
\hline
\end{tabular}

In addition to the total impacts the IMPLAN multiplier model provides a set of disaggregated multipliers that can be used to estimate the indirect impacts and the induced impacts separately from the total impact at the regional level. The indirect impact is the additional regional economic activity of the supply chain network caused by the economic activity of the direct industry. The induced impact is the additional regional economic activity of all other unrelated firms and households caused by the economic activity of both the direct and indirect industry impacts.

This study encountered a number of complications. Because of the fluid nature of the industry, networks of firms and individuals form for short periods of time, days or weeks in some cases or months for feature films, and then separate and form new networks for subsequent projects. The result is that identifying what is a direct impact versus an indirect impact can be hard, and this is especially difficult for feature films being produced by outside the region movie companies. In this study, and based on the input of outside the region movie producers who have experience making movies in the Charlotte area, only 50 percent of outside feature movie budgets were treated as direct impacts for the Charlotte Region. The remainder of these budgets reflects expenses and salaries for firms and individuals, including actors and actresses, whose location or primary residences are located outside the Charlotte Region.

Using the IMPLAN regional model and multipliers the economic impacts of the film and video production and distribution industry were estimated for the Charlotte Region. These results are presented in the following section.

\section{REGIONAL IMPACTS}

For the Charlotte Region four different types of economic impacts generated by the film and video production and distribution industry were estimated based on 2008 activity levels. These impacts include: (1) output impacts; (2) employment impacts; (3) employee and freelancers compensation impacts; and (4) value added impacts. Each of these four impacts was estimated separately for the Non-Feature Film and Video sector (tabled as the Film 
and Video Impact) and for the Feature Film sector. The combined impacts of these two sectors are presented as the 2008 Total Impact for the Charlotte Region (all dollar denominated impacts are in 2008 dollars).

Output Impacts: Table 3.1 contains the estimated annual output impact on the Charlotte Regional economy of the film and video production and distribution industry. In the Charlotte Region the total direct spending by all the film and video production and distribution related firms and individuals in 2008 was $\$ 271,407,845$. Of these direct expenditures in the Charlotte Region, 249.6 million dollars originated with the Film and Video sector and 21.7 million dollars originated with the Feature Films/Independent Films/TV Movies sector. These direct impacts resulted in supply chain activity that produced $\$ 143,613,146$ of total indirect output impacts. The direct and indirect output expenditures further resulted in another $\$ 53,497,962$ of induced output impacts.

Table 3.1 shows the total output impact of the film and video production and distribution industry on the Charlotte Region economy in 2008 was $\$ 468,518,967$ which is the sum of the direct, indirect, and induced output impacts. This large economic impact is an indication of how important the film and video production and distribution industry is to the economic performance of the Charlotte Region economy.

Table 3.1

Charlotte Region 2008 Output Impacts

\begin{tabular}{|l|c|c|c|c|}
\hline \multicolumn{1}{|c|}{ Industry Sector } \\
\hline \multicolumn{1}{|c|}{ Item } & Direct & Indirect & Induced & Total \\
\hline Film and Video Output Impact & $\$ 249,662,496$ & $\$ 132,106,790$ & $\$ 49,211,671$ & $\$ 430,980,971$ \\
\hline Feature Film Output Impact & $\$ 21,745,349$ & $\$ 11,506,356$ & $\$ 4,286,291$ & $\$ 37,537,996$ \\
\hline Total Output Impact & $\mathbf{\$ 2 7 1 , 4 0 7 , 8 4 5}$ & $\mathbf{\$ 1 4 3 , 6 1 3 , 1 4 6}$ & $\mathbf{\$ 5 3 , 4 9 7 , 9 6 2}$ & $\mathbf{\$ 4 6 8 , 5 1 8 , 9 6 7}$ \\
\hline
\end{tabular}

Table 3.2 shows how this output impact was distributed among the Charlotte Region's industry sectors and is arranged in descending order of supply chain industry output impact identified as the indirect impact. Not surprisingly the largest indirect impact is on the motion picture and video industry itself. The extensive networking and collaboration common to this industry is reflected in the 59 million dollar supply chain impact of the identified direct expenditures of 271 million dollars. Table 3.2 further shows the supplier chain impacts on radio and television broadcasting follow with over 9 million dollars of indirect impact, and identify the 22 additional industry sectors with supply chain linkages (indirect impacts) that exceed one million dollars.

Employment Impacts: In addition to the output impacts, there are employment impacts for the film and video production and distribution industry in the Charlotte Region. Table 3.3 presents the 2008 impact of the film and video production and distribution industry on regional employment for the Non-Feature Film and Video sector (tabled as the Film and Video Impact) and for the Feature Films/Independent Films/TV Movies sector. In 2008 the Film and Video sector of the industry directly supported 1,286 full-time equivalent jobs and the Feature Films/Independent Films/TV Movies sector directly supported an additional 112 full-time equivalent jobs. The total direct employment impact of the film and video production and distribution industry in the Charlotte Region in 2008 was 1,398 full-time equivalent jobs. The two sectors combined to support an additional 726 indirect (supply chain) jobs and 329 induced jobs.

Table 3.4 shows how this employment impact was distributed among the Charlotte Region's industry sectors and is arranged in descending order of supplier chain industry employment impact identified as the Indirect impact. Again, the largest indirect impact is on the motion picture and video industry itself. The extensive networking and collaboration common to this industry is reflected in the 307 full-time indirect equivalent jobs created in the supplier chain resulting from the direct economic activity that created the 1,398 direct full-time equivalent jobs.

Table 3.4 further shows the supplier chain impacts on the real estate sector follow with 40 full-time equivalent jobs of indirect impact, and identify the 23 additional industry sectors with supply chain linkages (indirect impacts) that exceed 5 or more full time equivalent jobs in the Charlotte Region. Sectors with supply chain linkages (indirect impacts) that exceed 5 or more full time equivalent jobs in the Charlotte Region. 
Compensation Impacts: In addition to the output and employment impacts, estimates of employee and freelancers compensation impacts for the Charlotte Region were made and these impacts were reported in Table 3.5. Compensation consists of all wage and income benefits and non-wage benefits.

Table 3.2

Charlotte Region

2008 Output Impacts by Industry

\begin{tabular}{|c|c|c|c|c|c|}
\hline \\
\hline $\begin{array}{l}\text { IMPLAN } \\
\text { Code }\end{array}$ & Industry & Direct & Indirect & Induced & Total \\
\hline 418 & Motion picture and video industries & $\$ 271,407,844$ & $\$ 59,631,674$ & $\$ 93,666$ & $\$ 331,133,198$ \\
\hline 420 & Radio and television broadcasting & $\$ 0$ & $\$ 8,929,279$ & $\$ 80,202$ & $\$ 9,009,480$ \\
\hline 431 & Real estate & $\$ 0$ & $\$ 8,470,451$ & $\$ 2,690,563$ & $\$ 11,161,014$ \\
\hline 323 & Audio and video media reproduction & $\$ 0$ & $\$ 6,794,788$ & $\$ 8,840$ & $\$ 6,803,629$ \\
\hline 421 & Cable networks and program distribution & $\$ 0$ & $\$ 3,228,745$ & $\$ 492,887$ & $\$ 3,721,632$ \\
\hline 450 & $\begin{array}{l}\text { All other miscellaneous professional and } \\
\text { technical }\end{array}$ & $\$ 0$ & $\$ 3,084,176$ & $\$ 80,999$ & $\$ 3,165,175$ \\
\hline 303 & Computer storage device manufacturing & $\$ 0$ & $\$ 3,052,881$ & $\$ 44,512$ & $\$ 3,097,394$ \\
\hline 390 & Wholesale trade & $\$ 0$ & $\$ 2,864,042$ & $\$ 2,687,328$ & $\$ 5,551,370$ \\
\hline 422 & Telecommunications & $\$ 0$ & $\$ 2,733,081$ & $\$ 936,093$ & $\$ 3,669,174$ \\
\hline 30 & Power generation and supply & $\$ 0$ & $\$ 2,401,702$ & $\$ 1,302,635$ & $\$ 3,704,338$ \\
\hline 324 & $\begin{array}{l}\text { Magnetic and optical recording media } \\
\text { manufacturing }\end{array}$ & $\$ 0$ & $\$ 2,186,902$ & $\$ 7,409$ & $\$ 2,194,311$ \\
\hline 430 & $\begin{array}{l}\text { Monetary authorities and depository credit } \\
\text { intermediaries }\end{array}$ & $\$ 0$ & $\$ 2,033,726$ & $\$ 1,370,450$ & $\$ 3,404,177$ \\
\hline 451 & Management of companies and enterprises & $\$ 0$ & $\$ 1,704,738$ & $\$ 423,222$ & $\$ 2,127,959$ \\
\hline 481 & Food services and drinking places & $\$ 0$ & $\$ 1,686,467$ & $\$ 3,224,053$ & $\$ 4,910,520$ \\
\hline 447 & Advertising and related services & $\$ 0$ & $\$ 1,656,991$ & $\$ 60,430$ & $\$ 1,717,420$ \\
\hline 413 & Newspaper publishers & $\$ 0$ & $\$ 1,486,582$ & $\$ 78,675$ & $\$ 1,565,257$ \\
\hline 474 & $\begin{array}{l}\text { Promoters of performing arts and sports and } \\
\text { agents }\end{array}$ & $\$ 0$ & $\$ 1,300,291$ & $\$ 41,802$ & $\$ 1,342,094$ \\
\hline 454 & Employment services & $\$ 0$ & $\$ 1,288,972$ & $\$ 148,874$ & $\$ 1,437,846$ \\
\hline 425 & $\begin{array}{l}\text { Non-depository credit intermediation and } \\
\text { related }\end{array}$ & $\$ 0$ & $\$ 1,245,711$ & $\$ 565,707$ & $\$ 1,811,418$ \\
\hline 438 & Accounting and bookkeeping services & $\$ 0$ & $\$ 1,233,216$ & $\$ 216,186$ & $\$ 1,449,401$ \\
\hline 472 & Spectator sports & $\$ 0$ & $\$ 1,220,716$ & $\$ 114,750$ & $\$ 1,335,466$ \\
\hline 437 & Legal services & $\$ 0$ & $\$ 1,192,346$ & $\$ 580,634$ & $\$ 1,772,980$ \\
\hline 43 & $\begin{array}{l}\text { Maintenance and repair of nonresidential } \\
\text { buildings }\end{array}$ & $\$ 0$ & $\$ 1,179,967$ & $\$ 168,915$ & $\$ 1,348,881$ \\
\hline 416 & Database- directory- and other publishers & $\$ 0$ & $\$ 1,129,103$ & $\$ 67,646$ & $\$ 1,196,749$ \\
\hline 394 & Truck transportation & $\$ 0$ & $\$ 911,271$ & $\$ 712,845$ & $\$ 1,624,116$ \\
\hline & Total & $\$ 271,407,845$ & $\$ 143,613,146$ & $\$ 53,497,962$ & $\$ 468,518,967$ \\
\hline
\end{tabular}

Table 3.3

Charlotte Region

2008 Employment Impacts

\begin{tabular}{|c|c|c|c|c|}
\hline \multicolumn{5}{|l|}{ Industry Sector } \\
\hline Item & Direct & Indirect & Induced & Total \\
\hline Film and Video Employment Impact & 1,286 & 668 & 303 & 2,256 \\
\hline Feature Film Employment Impact & 112 & 58 & 26 & 197 \\
\hline Total Employment Impact & 1,398 & 726 & 329 & 2,453 \\
\hline
\end{tabular}


Table 3.4

Charlotte Region

Employment Impacts by Industry

\begin{tabular}{|c|c|c|c|c|c|}
\hline IMPLAN Code & Industry & Direct & Indirect & Induced & Total \\
\hline 418 & Motion picture and video industries & 1,398 & 307 & 0 & 1,706 \\
\hline 431 & Real estate & 0 & 40 & 13 & 53 \\
\hline 454 & Employment services & 0 & 34 & 4 & 38 \\
\hline 420 & Radio and television broadcasting & 0 & 31 & 0 & 31 \\
\hline 474 & Promoters of performing arts and sports and agents & 0 & 27 & 1 & 28 \\
\hline 481 & Food services and drinking places & 0 & 23 & 44 & 68 \\
\hline 323 & Audio and video media reproduction & 0 & 20 & 0 & 20 \\
\hline 472 & Spectator sports & 0 & 14 & 1 & 15 \\
\hline 390 & Wholesale trade & 0 & 12 & 11 & 23 \\
\hline 447 & Advertising and related services & 0 & 10 & 0 & 10 \\
\hline 458 & Services to buildings and dwellings & 0 & 9 & 3 & 12 \\
\hline 438 & Accounting and bookkeeping services & 0 & 9 & 2 & 11 \\
\hline 413 & Newspaper publishers & 0 & 9 & 0 & 9 \\
\hline 43 & Maintenance and repair of nonresidential buildings & 0 & 8 & 1 & 9 \\
\hline 398 & Postal service & 0 & 8 & 2 & 10 \\
\hline 437 & Legal services & 0 & 7 & 4 & 11 \\
\hline 399 & Couriers and messengers & 0 & 6 & 1 & 7 \\
\hline 139 & Commercial printing & 0 & 6 & 0 & 6 \\
\hline 473 & Independent artists- writers- and performers & 0 & 5 & 0 & 5 \\
\hline 451 & Management of companies and enterprises & 0 & 5 & 1 & 7 \\
\hline 493 & Civic- social- professional and similar organizations & 0 & 5 & 6 & 11 \\
\hline 422 & Telecommunications & 0 & 5 & 2 & 7 \\
\hline 455 & Business support services & 0 & 5 & 1 & 6 \\
\hline 394 & Truck transportation & 0 & 5 & 4 & 9 \\
\hline \multirow[t]{2}{*}{444} & Management consulting services & 0 & 5 & 1 & 6 \\
\hline & Total & 1,398 & 726 & 329 & 2,453 \\
\hline
\end{tabular}

Table 3.5

Charlotte Region

2008 Employee and Freelancer Compensation Impacts

\begin{tabular}{|l|c|c|c|c|}
\hline \multicolumn{4}{|c|}{ Industry Sector } \\
\hline \multicolumn{1}{|c|}{ Item } & Direct & Indirect & Induced & Total \\
\hline Film and Video Compensation Impact & $\$ 64,150,264$ & $\$ 32,335,441$ & $\$ 15,307,495$ & $\$ 111,793,200$ \\
\hline Feature Film Compensation Impact & $\$ 2,503,823$ & $\$ 2,325,750$ & $\$ 1,176,463$ & $\$ 6,006,036$ \\
\hline Total Employee Compensation Impact & $\mathbf{\$ 6 6 , 6 5 4 , 0 8 7}$ & $\mathbf{\$ 3 4 , 6 6 1 , 1 9 1}$ & $\mathbf{\$ 1 6 , 4 8 3 , 9 5 8}$ & $\mathbf{\$ 1 1 7 , 7 9 9 , 2 3 6}$ \\
\hline Employee Compensation per Worker & $\mathbf{\$ 4 7 , 6 7 8}$ & $\mathbf{\$ 4 7 , 7 3 3}$ & $\mathbf{\$ 5 0 , 0 4 8}$ & $\mathbf{\$ 4 8 , 0 3 2}$ \\
\hline
\end{tabular}

Table 3.5 shows that $\$ 66,654,087$ of employee and freelancers' compensation in 2008 resulted from total direct activity related to the film and video production and distribution industry in the Charlotte region. This table shows that the average compensation per employee for the direct film and video production and distribution jobs was $\$ 47,678$ per year in 2008. In addition to the direct compensation impact the Charlotte Region film and video production and distribution industry generated additional indirect (supply chain) compensation impacts in 2008 of $\$ 34,661,191$ and induced compensation impacts of $\$ 16,483,958$. Overall, the film and video production and distribution industry activity in the Charlotte Region increased 2008 total employee compensation by $\$ 117,799,236$ with an overall average compensation of $\$ 48,032$ per worker. This report does not contain occupational compensation estimates for the film and video industry occupations identified earlier. The information contained in Table 1.1 for the 2008 average compensation by occupational category within the film and video industry does provide measurement of the differences in compensation by category for 2008.

Value Added Impacts. The output impacts reported earlier estimate the total spending in the Charlotte Region generated by the film and video production and distribution industry measured by the final selling prices of goods and services. Value added impacts measure the value of regional inputs included in the final selling price of a good 
or service. These value added impacts would be interpreted as the impact of the Charlotte region film and video production and distribution industry on Gross State Product (GSP) divided between North and South Carolina. GSP is a state measure analogous to Gross Domestic Product (GDP) for the national economy. Table 3.6 presents the estimated value added impacts by film and video production and distribution sector for the region.

Table 3.6

Charlotte Region

2008 Value Added Impacts

\begin{tabular}{|l|c|c|c|c|}
\hline \multicolumn{4}{|c|}{ Industry Sector } \\
\hline \multicolumn{1}{|c|}{ Item } & Direct & Indirect & Induced & Total \\
\hline Film and Video Value Added Impact & $\$ 80,756,616$ & $\$ 49,543,536$ & $\$ 29,514,526$ & $\$ 159,814,678$ \\
\hline Feature Film Value Added Impact & $\$ 4,042,425$ & $\$ 4,315,191$ & $\$ 2,570,685$ & $\$ 10,928,301$ \\
\hline Total Value Added Impact & $\mathbf{\$ 8 4 , 7 9 9 , 0 4 1}$ & $\mathbf{\$ 5 3 , 8 5 8 , 7 2 7}$ & $\mathbf{\$ 3 2 , 0 8 5 , 2 1 1}$ & $\mathbf{\$ 1 7 0 , 7 4 2 , 9 7 9}$ \\
\hline
\end{tabular}

Overall, the film and video production and distribution industry in 2008 was estimated to have a direct value added impact of $\$ 84,799,041$ and a total value added impact on the Charlotte Region economy of $\$ 170,742,979$. This total value added impact includes $\$ 53,853,727$ in indirect (supply chain) impact and $\$ 32,085,211$ of induced impact. Based on the activity and contribution of the film and video production and distribution industry in the Charlotte Region, the combined state levels of GSP in North and South Carolina was increased by over 170 million dollars in 2008. The size of this impact suggests how important the film and video production and distribution industry is to the Charlotte Region and the two state economies.

\section{SUMMARY AND CONCLUSIONS}

This report provides measurement of the 2008 economic impacts of the film and video production and distribution industry on the Charlotte regional economy. This regional economy is anchored by Charlotte, and is composed of twelve North Carolina counties and four South Carolina counties. The economic impacts include: (1) output impacts; (2) employment impacts; (3) employee and freelancers compensation impacts; and (4) value added impacts.

Using an IMPLAN model for the sixteen counties that make-up the regional economy the 2008 economic impacts of the film and video production and distribution industry were measured for the Charlotte Region. Table 4.1 provides a summary of the 2008 impacts for each of the four impacts identified above. The results are disaggregated to identify the direct economic impact of the film and video production and distribution industry, the indirect (supply chain) impact of the industry, and the induced (re-spending) impact of the industry. The total impact of the industry is then the sum of direct, indirect, and induced impacts.

Table 4.1 shows that in 2008 the direct impact of the film and video production and distribution industry on the Charlotte Region was to: (1) increase output by over 271 million dollars, (2) support 1,398 full-time equivalent jobs, (3) increase employee and freelancer compensation by over 66 million dollars with average compensation of $\$ 47,678$ per job, and (4) to increase the value added produced in the region by over 84 million dollars.

Table 4.1

Charlotte Region

Summary of 2008 Impacts

\begin{tabular}{|l|c|c|c|c|}
\hline \multicolumn{1}{|c|}{ Item } & Direct & Indirect & Induced & Total \\
\hline Output Impact & $\$ 271,407,845$ & $\$ 143,613,146$ & $\$ 53,497,962$ & $\mathbf{\$ 4 6 8 , 5 1 8 , 9 6 7}$ \\
\hline Employment Impact & 1,398 & 726 & 329 & $\mathbf{2 , 4 5 3}$ \\
\hline Employee Compensation Impact & $\$ 66,654,087$ & $\$ 34,661,191$ & $\$ 16,483,958$ & $\mathbf{\$ 1 1 7 , 7 9 9 , 2 3 6}$ \\
\hline Employee Compensation per Worker & $\$ 47,678$ & $\$ 47,733$ & $\$ 50,048$ & $\mathbf{\$ 4 8 , 0 3 2}$ \\
\hline Value Added Impact & $\$ 84,799,041$ & $\$ 53,858,727$ & $\$ 32,085,211$ & $\mathbf{\$ 1 7 0 , 7 4 2 , 9 7 9}$ \\
\hline
\end{tabular}

Adding the indirect and induced impacts to these direct impacts the economic impacts of the film and video production and distribution industry on the Charlotte Region economy in 2008 were estimated to: (1) increase output by over 468 million dollars, (2) support 2,453 full-time equivalent jobs, (3) increase employee and freelancer 
compensation by over 117 million dollars with average compensation of $\$ 48,032$ per job, and (4) to increase the value added produced in the region by over 170 million dollars.

The average 2008 compensation per job of $\$ 48,032$ for the jobs supported by the film and video production and distribution industry on the Charlotte Region are significantly higher than both the 2008 North Carolina and South Carolina All Occupation averages of $\$ 36,900$ and $\$ 33,720$ respectively. The film and video production and distribution industry in the Charlotte Region supported 2,453 full-time equivalent jobs at this significantly higher average compensation level. The large total output impact, over 468 million dollars, and valued added impact, over 170 million dollars, provide further evidence of the productivity and value of the film and video production and distribution industry to the Charlotte Region economy.

\section{AUTHOR INFORMATION}

Dr. John E. Connaughton is Babson Capital Professor of Financial Economics and Director of the Babson Capital/UNC Charlotte Economic Forecast at The University of North Carolina at Charlotte. He received his Ph.D. degree in Economics from Northeastern University in Boston, Massachusetts and has been at UNC Charlotte since 1978. Dr. Connaughton is a past president of the Southern Regional Science Association and the Carolinas Section of the National Association of Business Economists (NABE).

Dr. Madsen is Professor of Economics at The University of North Carolina at Charlotte. He earned his B.S. in economics from the University of Illinois and earned his M.B.A. and D.B.A. degrees from Arizona State University. He joined the faculty at UNC Charlotte in 1977. He teaches econometrics, business and economic forecasting, labor economics, and economics of business decisions. Dr. Madsen works as a consultant and expert witness in areas dealing with labor economics, forecasting, and statistical decision making.

\section{REFERENCES}

1. Abdulkadri, Abdul and Steven R. Miller, The Economic Impact of Michigan's Motion Picture Industry, Michigan State University, 2007

2. Canfield, Joshua, W. Jared Dupree, Paulo Guimaraes, and Douglas Woodward, Evaluating the Economic Impacts of film Production Incentives in South Carolina, University of South Carolina Moore School of Business, 2008

3. ECONorthwest, The Economic Impact of Film and Video Productions on Seattle, Seattle Mayor's Office of Film and Video, 2003

4. ESI Corporation, Analysis of the Film and Video Industry in Arizona, Arizona Department of Commerce, 2004

5. Ernst \& Young, Economic and Fiscal Impacts of the New Mexico Film Production Tax Credit, New Mexico State Film Office and State Investment Council, 2009

6. Harper, Rick and Phyllis K. Pooley, Analysis of the Florida Film and Entertainment Industry, Haas Center for Business Research and Economic Development, University of West Florida, 2009

7. Josephson, Alec and Robert Whelan, An Economic Impact Analysis for the Oregon Film \& Video Office, ECONorthwest, 2006

8. Merkowitz, Howard, Estimating the Impact of the Massachusetts Film Production Tax Incentives -A Preliminary Analysis, Massachusetts Department of Revenue, 2008

9. Montana Film Office and ArtsMarket, Inc., The Big Sky on the Big Picture, The Montana Department of Commerce, 2005

10. Nelson, Mary, An Economic Analysis of Virginia's Film and Video Production-Distribution Industry, Virginia Commonwealth University, 2006

11. Porter, Michael E., The Competitive Advantage of Nations, Basic Books, New York, 1990.

12. The Charlotte Regional Film Commission, Charlotte Regional Film and Video Guide 2008-2009, Oz Publishing, Inc., Atlanta, 2008

13. U.S. Department of Labor, Bureau of Labor Statistics, Occupational Employment and Wages, May 2008, http://www.bls.gov/oes/2008/may/oes_16740.htm 


\section{APPENDIX}

The Charlotte Regional Partnership Economic Area County Profiles

\begin{tabular}{|c|c|c|c|c|}
\hline County & 2008 Population & Area (sq. miles) & $\begin{array}{c}\text { Population Density per } \\
\text { Square Mile } \\
\end{array}$ & Number of Industry Firms* \\
\hline \multicolumn{5}{|l|}{ North Carolina } \\
\hline Alexander & 36,537 & 263 & 139 & 4 \\
\hline Anson & 25,162 & 537 & 47 & 0 \\
\hline Cabarrus & 168,740 & 365 & 462 & 20 \\
\hline Catawba & 157,079 & 414 & 379 & 28 \\
\hline Cleveland & 99,015 & 469 & 211 & 4 \\
\hline Gaston & 206,679 & 364 & 568 & 20 \\
\hline Iredell & 155,359 & 597 & 260 & 16 \\
\hline Lincoln & 74,746 & 307 & 243 & 16 \\
\hline Mecklenburg & 890,515 & 546 & 1,631 & 324 \\
\hline Rowan & 139,225 & 524 & 266 & 4 \\
\hline Stanly & 59,614 & 404 & 148 & 4 \\
\hline Union & 193,255 & 640 & 302 & 46 \\
\hline \multicolumn{5}{|l|}{ South Carolina } \\
\hline Chester & 32,618 & 586 & 56 & 4 \\
\hline Chesterfield & 42,882 & 806 & 53 & 0 \\
\hline Lancaster & 75,913 & 555 & 137 & 0 \\
\hline York & 217,448 & 696 & 312 & 24 \\
\hline Regional Totals & $2,574,787$ & 8,073 & & 514 \\
\hline
\end{tabular}

*2006 County Business Patterns, U.S. Census Bureau 